\title{
STRATEGIC GLOBAL HUMAN RESOURCE MANAGEMENT: THE ROLE OF INPATRIATE MANAGERS
}

\author{
Michael G. Harvey \\ Milorad M. Novicevic \\ University of Oklahoma, Norman, OK, USA \\ Cheri Speier \\ Michigan State University, MI, USA
}

\begin{abstract}
The need for highly qualified multicultural managers will increase as more organizations globalize their operations. These global managers may be perceived as organizational resources and, therefore, a resource-based view of human resource management is utilized. At the same time, relational view of human capital provides insight into the value of managers who have unique local market knowledge (i.e., social knowledge). By integrating the two aspects of the resource-based view, one can develop a dynamic capabilities approach to staffing global assignments. Within this integrative theoretical perspective, inpatriate managers (i.e., host or third country managers who are transferred into the home country organization on a semi-permanent to permanent basis) can be explored as a potential pool of uniquely qualified global managers to be utilized in global organizations. It is envisioned that through this unique building of managerial talents, organizations can develop/maintain a distinct competitive advantage in the markets they enter. This article explores inpatriation as an innovative means to develop managers as strategic resources to be used in formulating and implementing a global strategic plan.
\end{abstract}

As globalization becomes the normative strategy for organizations, one of the critical success factors centers on amassing an adequate number of competent global managers to implement global strategies (Gregersen, Morrison, \& Black, 1998). The skill set required of global managers to achieve success in a hyper-competitive global marketplace necessitates recalibrating the selection and training processes used in the past. A successful global manager will

Direct all correspondence to: Michael G. Harvey, Puterbaugh Chair of American Free Enterprise, Michael F. Price College of Business, University of Oklahoma, Norman, OK 73019-2007, USA. E-mail: mharvey@ou.edu 
have to possess a complex amalgamation of technical, functional, cultural, social, and political skills (Bartlett, 1986; Bartlett \& Ghoshal, 1994; Ghoshal \& Bartlett, 1997). Finding and retaining these managers in adequate numbers for the firm's strategic intent represents one of the major challenges for global human resource managers (Harvey, 1997; Lado \& Wilson, 1994; Pfeffer, 1994).

Today's global manager is envisioned to act as a versatile boundary spanner between the home and host country organization and, at the same time, between the global organizational network's need for consistency and the contextual market requirements of the host country's "local" marketplace (Bartlett \& Ghoshal, 1994; Ghoshal \& Bartlett, 1997). This duality of perspectives has escalated the sophistication of capability for managing globally to a point where traditional pools of candidates hired and developed on an assignment-specific basis cannot meet the quantity or quality expectations of global organizations. This sophistication is exacerbated when one considers the future markets for many global organizations will emanate emerging economies, such as China, Russia, India, Indonesia, Thailand, Malaysia, Turkey, Philippines, Eastern European countries, and Africa (Arnold \& Quelch, 1998; Garten, 1996, 1997a,b). It has been estimated that by 2,025 7/8ths of the world population of 8.3 billion inhabitants will reside in Asia and Africa, which raises the rhetorical question "how will these global population and economic shifts impact the management practices of global organizations in the twenty-first century and beyond?" (Bridging the Gaps: The World Health Report, 1995; The State of World Population, 1995; World Population Prospects, 1996).

This article examines an emerging innovative HR practice of inpatriation (i.e., host or third country managers who are transferred into the home country organization on a semi-permanent to permanent basis to enhance globalization of its business activities) (Harvey, 1997) as a means to augment the talent available to manage in the developing countries of the world. The article is divided into four sections: (1) a resource-based view (RBV) of the firm as a theoretical basis for explaining implementation of a strategic global human resource management (SGHRM); (2) the emergence of the inpatriate manager pool; (3) strategic utilization of inpatriate managers in SGHRM; and (4) designing a competency-based SGHRM system to gain a sustainable competitive advantage. Each of these sections is developed in an effort to highlight a critical candidate pool, inpatriate managers, as high-potential global managers of the future.

\section{RESOURCE-BASED VIEW OF THE FIRM}

The proposed model of RBV of inpatriation practice in the SGHRM system of a global organization is shown in Fig. 1. In an effort to examine when expatriate and inpatriate managers would be utilized most effectively in a global context, the theoretical perspective of the RBV of the firm is used as the explanatory framework for SGHRM. The theory centers on the effective and efficient bundling, utilization, and deployment of a global organization's resources. By employing this theory, one can develop a multi-dimensional 


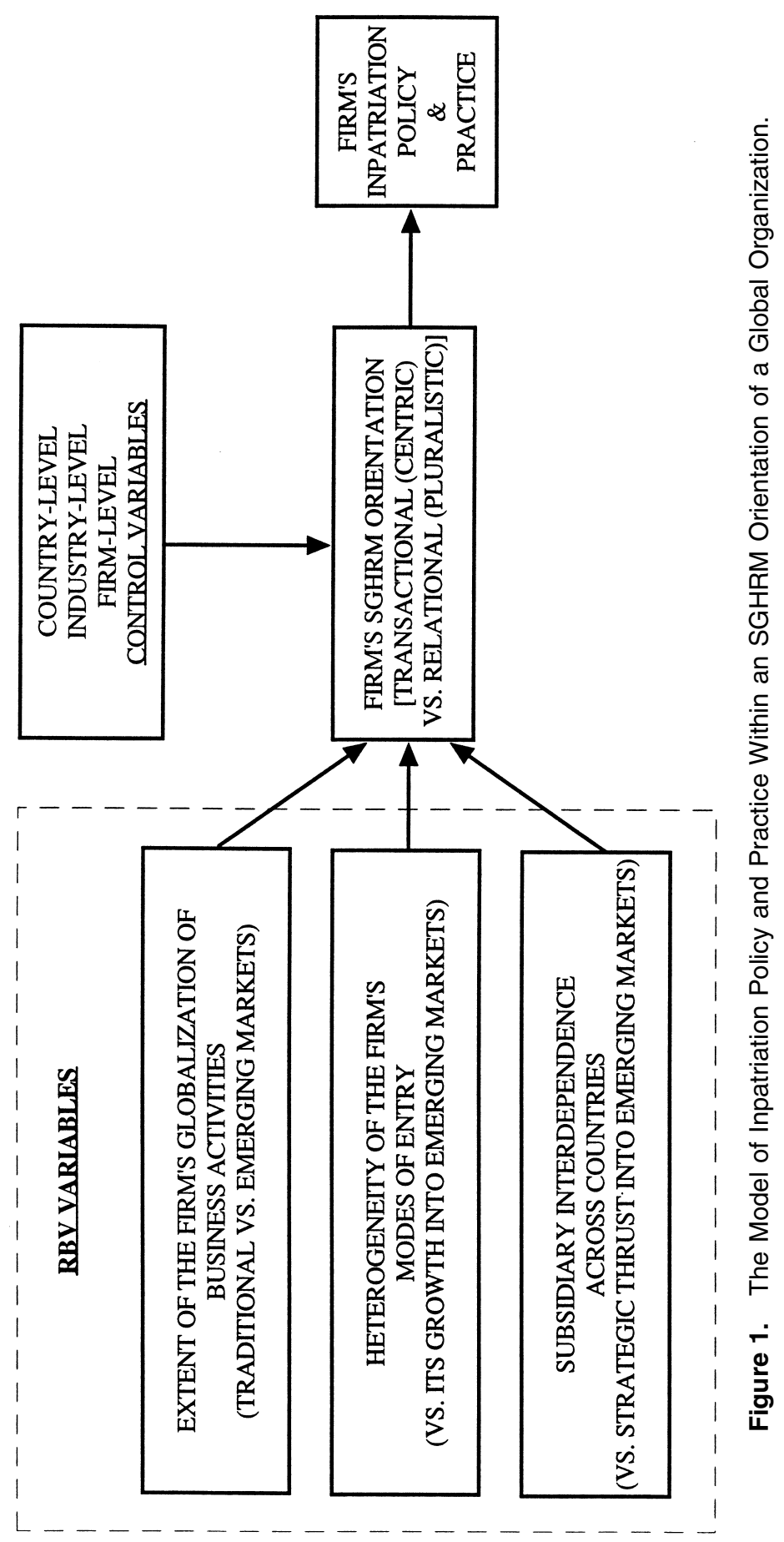


perspective on the drivers of inpatriation practice to insure execution of global strategic actions by the focal organization. Therefore, in this section, the emergence of the SGHRM system is discussed and a set of the RBV theory-based propositions are derived to explain the relationships proposed in the model shown in Fig. 1.

\section{Internal Firm Resources}

The RBV focuses on the firm-level infrastructure, processes, and related behaviors that provide a global organization with a unique competitive posture both globally and at the local market level (Bartmess \& Cerny, 1983; Kamoche, 1996; Ulrich, 1993). RBV envisions the organization as a unique bundle of accumulated tangible and intangible resource stocks. These resources can be utilized in a number of ways/paths that represent the strategic intent of the organization. Most frequently, resources are conceived of as internal attributes including tangible assets, specific internal capabilities, processes/procedures, routines, and knowledge, which are linked to or are controlled by the organization (Barney, 1991; Conner, 1991; Constantin \& Lusch, 1994; Roth, 1995).

The bundling of resources into unique strategies is the means to gaining sustainable competitive advantage and distinctive market processes. These resources must be (1) valuable, (2) rare, (3) imperfectly mobile, and (4) inimitable to provide a sustained competitive advantage against global competitors (Barney, 1991). Resources constantly flow throughout the firm, however, it is their cumulative effect that provides the organization with a unique profile or path based on the strategies used to employ the resources. These "paths" develop into competitive postures presenting a dynamic optimization problem to the firm - "how to maintain resources in various bundles to increase competitive advantage against global competitors" (Collis, 1991).

A distinction is normally made between resources and capabilities, in that, "resources are stocks of available factors that are owned or controlled by the organization and capabilities are an organization's capacity to deploy resources" (Amit \& Schoemaker, 1993, p. 35). Following Penrose's (1959) conceptualization of resources, the value of a resource is seen in terms of its potential to yield competitive differentiation and/or customer value delivery. Value is maximized when capabilities are deployed to utilize resources in a means to provide a distinctive competency and relative sustained advantage over competitors (Kamoche, 1996; Oliver, 1997). Of particular relevance is the concept of collective learning as an intangible resource that can add value by providing information on adaptation to the marketplace. These internal learning capabilities are core skills that, over time, develop competencies difficult for competitors to imitate (Hall, 1993; Klein, Edge, \& Kass, 1991). Therefore, these intangible learning skills are the foundation to gain an enduring distinctive competency, thus requiring adequate HRM policies and practices.

An RBV of SGHRM suggests that human resource policies and practices must not be viewed as merely technical administrative procedures for 
managing human resources, but rather as valuable processes that develop human resources with unique competitive capabilities (Kamoche, 1996; Oliver, 1997). A fundamental premise of the RBV is that global organizational competencies are heterogeneous and immobile and therefore, provide the means for sustaining competitive advantage (Lado \& Wilson, 1994; Roth \& O'Donnell, 1996). SGHRM can contribute to sustained competitive advantage through facilitating the acculturation of distributed competencies that are unique to the organization relative to its human resource system and personnel. More specifically, these competencies involve creating a collective experience base and learning capability that is difficult to replicate (Roth \& O'Donnell, 1996; Taylor, Beechler, \& Napier, 1996). Both tangible and intangible dimensions of human resources are essential in developing a global competitive personnel profile that is unique, valuable, difficult to replicate, and provides the organization with a sustainable competitive advantage. Tangible human resource dimensions relate to the process, procedures, and systems established to identify, select, train, motivate, and retain the most competent personnel in the organization. Alternatively, intangible dimensions of human resources include the culture, learning capability, innovativeness, and collective action of the employees. Leveraging a firm's internal resources across its global network requires competent boundary-spanning managers developed within the firm's SGHRM system. Expatriates, having been socialized and developed in the headquarters, possess an intimate knowledge of the firm's internal resources, both in terms of their tangible and intangible dimensions, therefore, it is proposed:

Proposition 1. If the firm's internal resources are critical for creating and sustaining a competitive advantage against rivals in a foreign market, then the global organization will assign management of that market to an expatriate manager.

\section{Firm Relational Resources}

The RBV encompasses both firm internal resources emphasizing the capabilities of the intra-organizational network and the relational view (Dyer \& Singh, 1998) of the global organization, which is focused on the resources emphasizing the inter-organizational capabilities of the network external to the firm. Just as internal processes, practices, and people are viewed as assets, so too are relational ones that integrate consumers and channels-of-distribution and other external assets. The relational view suggests that these types of assets must be cultivated, encouraged, and protected and are not simply the residual outcome of marketing actions (Harvey \& Lusch, 1997; Hunt \& Morgan, 1995). Relational perspective is a corollary to RBV in that both identify tangible and intangible assets as having value and uniqueness in creating/sustaining competitive advantage (Aaker \& Jacobsen, 1994; Day, 1994; Day \& Fahey, 1988). 
Relational assets arise form the commingling of the organization's internal assets with entities in its external environment. Relational assets are typically one of two types: stakeholder-specific or market-specific (Strivastava, Shervani, \& Fahey, 1998). Relational stakeholder-specific assets are built around the relationships a global organization may develop in a specific market with key external stakeholders, including ultimate customers, strategic alliance partners, channel-of-distribution members, and government agencies (Anderson \& Narus, 1990; Day, 1994; Douglas \& Craig, 1991; Morgan \& Hunt, 1994; Nevin, 1995). Alternatively, market-specific assets are related to the type of knowledge the global organization possesses about the local environment (e.g., facts, perceptions, beliefs, assumptions, and projections of local market opportunities; Strivastava et al., 1998). Tacit knowledge of local markets is perhaps the ultimate source of value and provides the basis for developing unique competitive strategies (Drucker, 1993; Leonard-Barton, 1995). In many cases, this contextual knowledge allows the global organization to command competitive advantage by exploiting first-moves advantages relative to local and other global competitors (Kerin, Varadarjan, \& Peterson, 1992).

Relational assets present profound difficulties to global rivals attempting to competitively match the contextual strategies of the firm. This is particularly true regarding the firm's tacit knowledge of the local environment and specific customers (Pine, 1993). In addition, if a network of intangible market-specific assets can be developed within countries, and most importantly, between countries, the global organization can reap disproportionate rents in comparison to competitors. At the center of many of these relational assets are people and their ability to provide unique knowledge, information, and relations to develop a strategic competitive advantage.

From an SGHRM perspective, relational assets are associated with the practice of selecting and retaining global managers that have social knowledge of the country/market and local stakeholders and at the same time have an understanding of the global function of the organization to allow coordination among foreign subsidiary units. This dual stream of knowledge is essential in coordinating global activities and acting at the local level to gain competitive advantage. While the firm's internal resources require support by the internal personnel and human resource management system as assets, relational market-specific resources require support by external personnel. These boundary-spanning individuals play a central role in implementing and maintaining distinctive competitive strategies by providing personal contacts, which are the foundation of relationships and market intelligence and help to contextualize local strategies. A stock of knowledge is built up and reinforced through persistent application of social knowledge and adaptive learning over time, which then can be translated into a dynamic distinctive competitive advantage (Snow \& Herbiniak, 1980; Sparrow, 1994). These dynamic characteristics become the ultimate competitive competency-learning and acting on integrated knowledge. Inpatriates, having acquired managerial experience and social knowledge in the local 
foreign markets, possess an intimate knowledge of the firm's relational resources, both in terms of their tangible and intangible dimensions. Therefore, it is proposed:

Proposition 2. If the firm's relational resources are critical for creating and sustaining a competitive advantage against rivals in a foreign market, then the global organization will assign management of that market to an inpatriate manager.

\section{Dynamic Capabilities from the Integration of Firm's Internal and Relational Resources}

Successful companies must actively seek "creative destruction" of their existing competencies to retain competitive advantage in the marketplace (Schumpter, 1934, 1942). Creative destruction in strategy is particularly important in complex, heterogeneous, rapidly changing (e.g., hyper-competitive) global markets. The process of continuous learning and the modification of resource bundles relative to the efficiency and effectiveness of strategies contribute to development of the firm's dynamic capabilities (Teece, 1988; Teece, Pisano, \& Shuen, 1997). Dynamic capabilities refer to the development of global management capabilities and difficult-to-imitate combinations of organizational, functional, and technological skills to gain/ sustain competitive advantage. Global competitiveness is characterized by timely response, rapid and flexible strategies, and management capability to effectively coordinate and re-deploy internal and relational resources (Teece et al., 1997). Applying dynamic capabilities to SGHRM has two core components: (1) dynamic-developing systemic global coherence while recognizing the unique features of each country's environment to facilitate customization of individual country strategies; (2) capabilities-focuses attention on the key role of managers in the adaptation, integration, and reconfiguring of both internal and relational resources to match the opportunities in the global and local marketplaces (Dierickx \& Cool, 1989; Teece et al., 1997).

The social infrastructure of a strategic path to exploit an organizational competency and create an "organizational advantage" is viewed as an asset in that the strategy differentiates the organization from other competitors and makes it difficult for competitors to imitate the strategic profile of the organization (Nahapiet \& Ghoshal, 1998). The selection of a specific strategy mode also represents a constraint on the organization in the form of an opportunity cost given the chosen strategic path. In the global competitive arena, the organization, at various points in time, makes long-term, quasiirreversible commitments of internal and relational resources to specific domains of expertise. Therefore, the global firm exploits existing internal and relational resources/capabilities while simultaneously creatively destroying this advantage to build newer capabilities that match the ever-changing opportunities in the consumer and competitive market (Teece, 1982). If 
controlling and modifying scarce assets effectively reflects a global competitive advantage, then it follows that skill acquisition, the innovation of knowledge and social knowledge, and learning become fundamental strategic options in a hyper-competitive global competitive marketplace (Teece et al., 1997). These are key concerns in SGHRM, which directly relate to developing a stock of global managers with the ability to learn more/faster than competitors' global managers.

The dynamic capabilities concept suggests developing a dynamic SGHRM system that allows for utilization of internal and relational (tangible and intangible, and local and global) resources matching the dynamics of the environment, thus adding an "action" dimension to the RBV of the firm. In addition, it is recognized that these strategies need to be continuously challenged and "destroyed" to evolve into strategies that are more attuned to changes in the global and local marketplaces. Globally competent managers are central to this conceptual development in that they are the ones that influence the conversion of assets into capabilities and, over time, learn to adapt strategy for competing effectively with global and local competitors. Therefore, these managers must have a comprehensive common knowledge base to compete globally and, at the same time, must have the specific social knowledge to develop contextual competitive strategies. Given this dual basis of knowledge, dynamic capabilities perspective suggests that the flow of human resources may be from headquarter to subsidiary or vice versa (Birkinshaw, Hood, \& Jonsson, 1998). When the global organization's strategy in a local foreign market requires a change in the resource base, expatriates will know the dynamics of firm internal resources, whereas inpatriates will know the dynamics of relational resources. As the development of an organization's dynamic capability requires a change in both aspects of the firm resources, it is proposed:

Proposition 3. If both internal and relational firm resources are critical for creating and sustaining a competitive advantage against rivals in a foreign market, then the global organization will bundle expatriate and inpatriate managerial resources to manage that market.

The firm's internal and relational resources enable disaggregation and dispersion of its global activities across its global network (Ghoshal, 1991). These activities distributed across country markets are implemented through the mechanisms of hard (bureaucratic) and soft (personnel) control. The degree of global integration of the firm's dispersed activities depends upon the firm's needs to preserve local responsiveness to individual country markets (Roth \& Nigh, 1992). The variables that capture this degree include: (1) extent of globalization in the firm's business activities; (2) heterogeneity of the firm's modes of entry across its global network; and (3) the level of horizontal interdependence among subsidiaries influencing the firm's strategic trust (Athanassiou \& Nigh, 1999). In effect, these variables influence the depth of the internal control mechanisms in the 
global organization and thus the salience of inpatriation policy and practice in the firm's SGHRM.

\section{Extent of the Firm's Globalization}

The extent of the firm's globalization of business activities reflects the share of its sales, employees and assets outside the borders of its home country (Sullivan, 1994). As this extent increases, the firm's need for local social knowledge increases (Kogut \& Zander, 1992). In other words, the global organization needs to integrate the local social knowledge across multiple country markets of specific, institutional and social environments. The multiplicity of local environments of varying cultural and economic level distance versus the home country increases the need for the firm's inclusion of inpatriation practice in its SGHRM system. Therefore, it is proposed:

Proposition 4. The greater the organization's extent of globalization, the more salient inpatriation practice in the global organization's SGHRM.

\section{Heterogeneity of the Firm's Modes of Entry}

The firm's modes of entry are heterogeneous across countries and subsidiaries in terms of modes of governance (exporting, licensing, franchising, joint ventures, and wholly owned subsidiaries). The modes with a controlling equity position are hierarchical modes of governance; the contractual modes are quasi-market modes of governance; and 50/50 joint ventures are a hybrid form.

Subsidiaries with a hierarchical mode of governance are more likely to be involved in value-adding activities and, therefore, are assigned to a centralized control by expatriates and inpatriates. If such subsidiaries are located in emerging, culturally and economically different countries, the firm's need for local social knowledge increases thus increasing the need for inpatriation practice in the global organization's SGHRM system. Therefore, it is proposed:

Proposition 5. The greater the heterogeneity of the firm's modes of entry across its global network, the more salient inpatriation practice in the global organization's SGHRM.

\section{Subsidiary Interdependence Across Countries}

The subsidiary interdependence across countries arises from the links of activities across markets formed as a horizontal value chain (Kogut, 1985). The coordination and integration of the horizontal subsidiary interdependencies is a complex task requiring local social knowledge of the linked country markets. This task becomes even more relevant as the firm's future strategic thrust 
involves planned growth into emerging, culturally and economically different markets. The higher the interdependence and cultural and economic difference between the linked local markets, the more salient the firm's need to include inpatriation practice into its SGHRM system. Therefore, it is proposed:

Proposition 6. The greater the level of horizontal interdependence among subsidiaries in culturally and economically distant markets from the home country market, the more salient inpatriation practice in the global organization's SGHRM system.

\section{INPATRIATE MANAGERS AS SUBSTITUTES AND COMPLEMENTS TO EXPATRIATES IN GLOBAL ORGANIZATIONS}

Diversity in an organization's global management team necessitates a flexible, dynamic human resource system that can accommodate the strengths and weaknesses of different management candidate pools. Specific to the inclusion of inpatriate managers into the global management team, the human resources function should recognize the contextual situations when the use of inpatriate managers is appropriate as substitutes and complements to expatriates. These situations include assignments where expatriates have performed poorly in the past and where there is a low probability of expatriate success in the future (e.g., emerging economies where there is great cultural and economic development distance between the home and host countries), but where most of the future growth of global organizations will come from in the next several decades.

A proactive utilization of inpatriates to accelerate the creation of multicultural management teams and globalization within an organization is predicated on recognizing the relative differences between expatriate and inpatriate managers as managerial resources of a global organization. It must be recognized that inpatriate managers have a distinct set of attributes that differentiate them from expatriates. However, at the same time, expatriates and inpatriates reflect a great deal of diversity as candidate pools. A direct comparison of expatriate and inpatriate candidate pools has identified a number of relevant differences (see Table 1). These differences may be used as a basis to determine in which types of countries (i.e., developed or emerging economies) each candidate pool's attributes would be most applicable.

The past research has also hypothesized that a declining number of expatriate managers will be used in the global organizations due, in part, to increased opportunities in markets in emerging economies. This belief is based on five trends: (1) expatriates' cost/failure/performance record is questionable in "difficult" assignments; (2) expatriation will become more complex due to the increasing number of expatriate dual-career couples and female expatriate candidates; (3) it will be more difficult to attract expatriates for assignments in emerging markets because of the poor business infrastructure (higher refusal rates) and these countries will present greater adjustment problems due to 
TABLE 1

Expatriate/Inpatriate Appropriateness Analysis

\begin{tabular}{|c|c|c|c|c|}
\hline \multirow[b]{3}{*}{ Candidate characteristics } & \multicolumn{4}{|c|}{ Location of assignment } \\
\hline & \multicolumn{2}{|c|}{ Expatriate } & \multicolumn{2}{|c|}{ Inpatriate } \\
\hline & Developed $^{\mathrm{a}}$ & Emerging & Developed & Emerging \\
\hline $\begin{array}{l}\text { Renewable resource } \\
\quad \text { (extended assignments) }\end{array}$ & $L^{b}$ & L & $\mathrm{H}$ & $\mathrm{H}$ \\
\hline $\begin{array}{l}\text { Willingness to accept } \\
\text { overseas position }\end{array}$ & $\mathrm{M}$ & L & $\mathrm{H}$ & $\mathrm{H}$ \\
\hline $\begin{array}{l}\text { Motivation to participate in } \\
\text { global assignments }\end{array}$ & M & L & $\mathrm{H}$ & $\mathrm{H}$ \\
\hline Relative cost characteristics & $\mathrm{H}$ & $\mathrm{H}$ & L & L \\
\hline $\begin{array}{l}\text { Flexibility } \\
\text { (social/cultural/family) }\end{array}$ & M & L & $\mathrm{H}$ & $\mathrm{H}$ \\
\hline Organizational cultural "fit" & $\mathrm{H}$ & L & $M$ & $\mathrm{H}$ \\
\hline Level of peer acceptance & $\mathrm{L}$ & M & M & $\mathrm{H}$ \\
\hline Headquarters confidence & $\mathrm{H}$ & $\mathrm{M}$ & M & $\mathrm{H}$ \\
\hline Level of stress & M & $\mathrm{H}$ & M & $\mathrm{L}$ \\
\hline $\begin{array}{l}\text { Internal political } \\
\text { understanding }\end{array}$ & $\mathrm{H}$ & $\mathrm{L}$ & M & $\mathrm{H}$ \\
\hline
\end{tabular}

Adapted from: Harvey, Speier, and Novicevic (1999b).

a Developed economies: emerging economies.

${ }^{b}$ Level of appropriateness of pool of candidates: $\mathrm{H}=$ High, $M=$ Moderate, $L=$ Low.

cultural novelty and level of economic development (higher failure rates); (4) conversely, inpatriate managers have the cultural/social background to adjust and address the problems in the emerging markets more effectively; and (5) global competitors will continue to adopt a multicultural perspective to their global operations (Harvey, Speier, \& Novicevic, 1999a).

Expatriate managers continue to provide global organizations with a pool of managers for overseas assignments and these managers are likely to be most effective in assignments in developed countries. It is anticipated that the difficulty of adjustment will be less in these countries and, therefore, the probability of attracting/retaining expatriate managers for these assignments will be higher. Utilizing expatriates also helps to insure that domestic managers can play a significant integrating role in the future leadership of the organization. If domestic managers are not expatriated, over time the organization would become control-dependent on the inpatriate and local managers for their knowledge of specific opportunities in global business (Kobrin, 1988). The expatriates' contribution to the multicultural management team provides the stabilizing referent control factor that most headquarters management prefers in the development of competitive strategy (Dadfer \& Gustavsson, 1992; Granstrand, Hakanson, \& Sjölander, 1993).

The role of inpatriates as a complementary control mechanism in globalizing the organization is somewhat more complex. Inpatriate managers play 
an important "linking pin" role between the headquarters and the emerging market that the organization is attempting to penetrate (Harvey et al., $1999 \mathrm{~b}, \mathrm{c}, \mathrm{d})$. The inpatriate manager would be formally located in the domestic organizational structure but would make frequent prolonged overseas trips to facilitate organizational globalization. By locating the inpatriate manager in the home country, top management would not experience the loss of control generally felt and partially experienced when using "headquarters-unsocialized" host country nationals located in their own country. In addition, by having the inpatriate managers domicile in the domestic organization, the process of both multiculturalism and trans-culturalism contributing to the global workforce diversity awareness can be activated. By utilizing the subtle cultural input of inpatriates, the organization has undertaken the first strategic step in developing a multicultural strategic leadership group capable of developing a global learning organization, which is needed to compete in the global marketplace effectively (Aguirre, 1997; Hofstede, 1980, 1984; McBride, 1992; McMillen, Baker, \& White, 1997; Nemetz \& Christensen, 1996; Reynolds, 1997).

Inpatriate managers, as substitutes and complements of expatriates, can also provide invaluable input in globalizing human resource management functions in emerging countries. They can give accurate advice on the adaptation of technical dimensions of the human resource processes (i.e., selection criteria, compensation plans, performance evaluations, and training/development of host country nationals). Inpatriates can also provide a means for transferring the appropriate dimensions of the home organization's culture to the host country subsidiary. The culturally sensitive "exporting" of corporate culture (i.e., roles, norms, values, climate) to operations in emerging markets allows for social control to be exercised in an acceptable and effective manner (Schein, 1983). Rather than enforcing an "outside" organizational culture, the inpatriate's insights into the host country culture allows the organizational climate in a local subsidiary to evolve over time.

Inpatriate managers could also provide mentoring to high potential managers from host country nations to insure a succession plan when new inpatriate managers are moved into the home country organization. It is important that inpatriates have a career path established allowing them every opportunity to become an integral component of the home country organization. In order to fully benefit from the multiculturalism created by the inpatriation of managers, they must be viewed as a part of the core global strategic management team and not as peripheral (Harvey et al., 1999b,c,d; Harvey \& Miceli, 1999).

\section{STRATEGIC UTILIZATION OF INPATRIATE MANAGERS IN SGHRM SYSTEMS}

The introduction of inpatriation policy and practice is envisioned and planned as an organization-wide process. The value and uniqueness of this practice can have important influence on strategic planning of the firm's operations. 
Specifically, inpatriates' cognitive flexibility would be invaluable when contextualizing functional aspects of various strategic elements in the firm's business plan. Because multiculturalism has been identified as one of the key elements in developing a global organization (Frey-Ridgway, 1997; Kamoche, 1996; Pechter, 1993), the innovative inpatriation practice appears to be an effective means to operationalize the concept.

Inpatriate managers can provide unique cultural/social/political insights into developing coherent strategies for creating competitive advantage across host country markets. Given their knowledge of the home and host countries, inpatriates can competently support global strategies and are keenly aware of the need to coordinate and maintain compatibility of local strategies and those of the global network. But, as with any firm-specific resource, inpatriates need to be assigned to situations in which the effects of their distinctive competencies can be maximized in terms of the value-added.

Specifically, three underlying factors need to be considered in determining when to utilize inpatriates most effectively in SGHRM systems: (1) stage of globalization of the organization - the strategic needs of the organization could/will vary to a degree by the level of involvement and strategic importance of the global marketplace (Anderson, 1993; Perlmutter, 1969; Sanders \& Carpenter, 1998); (2) the existing heterogeneity of global operations - the existing "path dependency" (i.e., inflexibility of past decisions of resource commitments to changes in the environment) established by past strategies of the organization as it globalized operations (Barney \& Wright, 1998; Child, 1996; Doz \& Prahalad, 1987); and (3) future strategic thrust-the strategic intent of the organization to expand its operations in new markets and how these strategies can influence the present level/complexity of the existing globalization strategy of the firm (Child, 1996; Fladmoe-Laindquist \& Tallman, 1994). It is important to note that each of these factors influencing an SGHRM orientation toward inpatriation practice is continuous and not bipolar (i.e., ranging from early to mature level of globalization). In an effort to illustrate a mechanism for determining the contingent appropriateness of the strategic use of inpatriates, a practical model of appropriateness of inpatriation practice is proposed (see Table 2).

Table 2 depicts the emergence of inpatriation practice at different stages of internationalization, by assessing the present strategic/geographic positioning and by forecasting the future strategic intent of the management based on firm resources and contextual factors. As the stage of globalization matures, the importance of the global market and the complexity of performance expectations increase and the integration of the social and functional knowledge of the inpatriate skill base becomes more crucial (Adler \& Ghadar, 1989; Anderson, 1993). In mature global organizations, inpatriate managers can provide new insights of how to develop and sustain competitive advantage in the local marketplace, while maintaining a global perspective to insure optimization of the global network.

The greater the heterogeneity of the planned global operations in the future (i.e., as the future strategic thrust increases the levels of difference from 
TABLE 2

Inpatriation Program Implementation Matrix ${ }^{a}$

\begin{tabular}{|c|c|c|c|c|c|c|}
\hline \multirow{3}{*}{$\begin{array}{l}\text { Inpatriates at } \\
\text { organizational levels }\end{array}$} & \multicolumn{6}{|c|}{ Influences on use/appropriateness of inpatriate managers } \\
\hline & \multicolumn{2}{|c|}{$\begin{array}{c}\text { Stage of } \\
\text { globalization }\end{array}$} & \multicolumn{2}{|c|}{$\begin{array}{c}\text { Existing } \\
\text { heterogeneity of } \\
\text { global operations }\end{array}$} & \multicolumn{2}{|c|}{ Future strategic thrust } \\
\hline & Early & Mature & Low & High & Concentrated & Diversified \\
\hline $\begin{array}{l}\text { Top management } \\
\text { team }\end{array}$ & Low & High & Low & High & Low & High \\
\hline $\begin{array}{l}\text { Senior functional } \\
\text { managers }\end{array}$ & Low & High & Low & High & Moderate & Moderate \\
\hline Middle managers & Low & High & Low & High & Moderate & Moderate \\
\hline $\begin{array}{l}\text { Operations } \\
\text { managers }\end{array}$ & Moderate & High & Low & High & Moderate & High \\
\hline "Specialists" & High & Low & Low & High & Low & High \\
\hline
\end{tabular}

${ }^{\mathrm{a}}$ Low $=$ Less applicable for inpatriates; Moderate = Moderately applicable for inpatriates; High = Highly applicable for inpatriates.

operations in the past international markets both economically and culturally), the more important the development of senior management level inpatriates is to the global organization. The increased complexity of operations due to operational diversity necessitates contextual social knowledge to insure that the coherent strategic thrust is translated and executed into an effective concrete program in the host country (Cappeli \& Singh, 1992; Frey-Ridgway, 1997). Through development of the inpatriation program as the part of the SGHRM system, the customization of plans can produce a competitive edge and is more likely to be a dynamic competency than when an assigned expatriate makes an independent decision in an economically and/or culturally distant host country (Harvey, 1993, 1997; Harvey \& Buckley, 1997). The less consistent the environment of the host country is with that of the home country, the more likely a variation of the firm strategy will not fit the local environmental context when the strategy is implemented. Therefore, control and consistency in these markets/subsidiaries are of primary concern to headquarters management. In these cases, an inpatriate manager can provide the necessary managerial skills to implement the plan effectively as the local environment requires modification of strategies.

The benchmarking of future strategies of competitor organizations should also be taken into consideration when assessing the effective firm-specific development of inpatriate managers. If competitor organizations are modifying their present positioning in the global marketplace dramatically and moving to new culturally/economically distant host countries, the need for inpatriate managers who can facilitate the firm's competitive response would increase. Global management staffing needs to not only match present competitive strategies, but also reflect on responses to the future intentions of 
global competitors (Schuler, Dowling, \& De Cieri, 1993). If inpatriate managers were developed with available dynamic competencies, they should be used to reposition the strategic response of the organization in the new heterogeneous markets.

\section{DESIGNING INPATRIATE POLICY WITHIN A FIRM'S SGHRM SYSTEMS}

The strategic value of inpatriate managers comes from possessing a unique ability to contextualize their social knowledge of foreign environments into firm-specific executable organizational strategies. These unique capabilities may qualify inpatriates to be considered as valuable and unique managerial resources having the ability to localize global strategies to the competitive characteristics of the local marketplace. To help insure that inpatriates have an opportunity to achieve this status, senior management must mobilize corporate human resource management to design an SGHRM system to: (1) provide extensive socialization of inpatriates into the parent organization; (2) include inpatriates into the integrating mechanisms of lateral coordination among subsidiaries; (3) plan opportunities for frequent communication and learning between expatriates and inpatriates; (4) provide a means for outstanding inpatriates to become a viable option in senior management succession plans; and (5) open opportunities for inpatriates to develop informal relationships with senior management members (Harvey, 1997; Harvey \& Buckley, 1997).

The strategic implications of designing an effective selection and development process in an SGHRM system fostering inpatriation must be socially complex to qualify the inpatriation process as an efficient mechanism for dynamic deployment of firm-relational resources. Therefore, it is very critical how the global organization selects, develops, and compensates inpatriates that have the potential of becoming senior management members.

Once retained by the global organization, inpatriate managers should be expected to spend at least 2 years with the parent organization to learn the company's organizational routines and culture before directly influencing or directing host country strategies. Corporate HR must bear in mind that these inpatriates are being groomed and developed for managerial oversight rather than staffing operations overseas. For management staffing purposes, the inpatriates must demonstrate the ability to perform in the "company-specific" way while overcoming any situational adversity. Human capital (Flamholtz \& Lacey, 1981) and social capital (Burt, 1992) theories posit that firm-specific competencies (i.e., the knowledge of internal organization routines, policies, and politics) "provide value only to a specific firm and are of no value to competing firms" (Barney \& Wright, 1998, p. 37). Most global companies give specific tests to audit these firm-specific competencies (Fuschberg, 1992). During the internship in the parent company, inpatriates are screened for the progress of their development in terms of competence in knowing the parent organization's management philosophy, interacting with home country 
managers, learning about the company's routines related to its overseas markets, developing skill sets for future assignments, and being adaptable, mobile, innovative, and entrepreneurial within the context of organizational guidelines. If inpatriates are developed in this manner, they can become corporate "enablers" who have an advanced set of functional and social skills strictly tailored to be operationalized within the firm's routines executed within its global network.

The inpatriate development program should be contextualized strictly within firm-specific routines (i.e., means to efficiently and effectively accomplish organizational goals through specific policies, procedures, tactics) and compatible to the organization's dynamic capabilities so that the skills acquired by inpatriates are neither easily imitable nor portable outside the firm's operating context. Less emphasis should be paid to cross-cultural-training, which is critical in the case of expatriates, because inpatriates' adjustment difficulties may be less than those of their expatriate counterparts as they come from cultural environments in which they were made aware of cultural and language differences early in their education (Dykeman, 1995). However, cultural sensitivity training is necessary for their socialization to the home corporate culture in terms of acquiring proper demeanor and interpretation frames (Harvey et al., 1999a). It is also critical for validating the inpatriation process in that inpatriates must view their commitment to the global operations of the company as the unique network to leverage their social and intellectual capital to provide the firm with a competitive advantage.

Inpatriates should be given a chance to develop and demonstrate a personal commitment to an international career early in the process/program. First, the global organization should reinforce the social and economic value and strategic advantage the inpatriate program gives to home country managers. Second, inpatriates should be given a career path that indicates how preparation and training relates to their future assignments in both home and host country operating units wherever in the value-chain their unique skills will provide the greatest impact. Third, an orientation program should also provide realistic career previews for inpatriates as well as the role of each assignment in developing a unique global strategic orientation for the organization. Fourth, through commitments to and socialization with expatriates, the company should create a basis for the inpatriate to develop realistic expectations about the content of assignments. The global organization thus exploits the synergetic value of expatriates and inpatriates working together and linked in transaction-specific relationships of managerial capital. Finally, the company should establish a clear link between the overseas operations and the long-term career path opportunities for the inpatriate within the company and, specifically, within the parent organization's senior management succession plans.

Once inpatriates are selected and trained, it is critical in their firm-specific development that they are integrated into functional teams with expatriates and senior level managers. This association is essential for expatriate executive development because the inpatriates can help to transfer a con- 
textual repertoire of social knowledge to expatriates enabling them to formulate and execute organizational strategies in the host country effectively. These interdependent practices help integrate corporate senior level initiatives when deployed in the global network but are also responsive to the specific local/regional markets demands. Inpatriates become a source of continued learning for expatriates as inpatriates are contextualizing their individual social and cognitive capital within firm-specific global strategies making them explicit for the local stakeholders.

Expatriates are thus introduced to the implicit formalization of how inpatriates' social knowledge about their regional markets is related to specific senior management initiatives. The expatriates, on the other hand, should be encouraged to provide cultural controls for the inpatriates' socialization process. This cultural control is necessary because inpatriates may be inclined to justify specific procedures for the senior management initiatives by grounding them into the logic of the institutional systems governing host country markets. The expatriates' control becomes a check-and-balance to the inpatriates' strategic focus to help insure that the home country institutional system is preserved and built into the inpatriates' strategic assumptions. The role of the expatriates' control is to insure that inpatriates do not fall into the "competency trap" in which they misjudge and inflate development needs or initiatives of a specific subsidiary in their region rather than provide realistic, factual input.

Performance benefits from utilizing inpatriates and expatriates appear to be difficult to replicate by competitors. However, the firm's ability to absorb these potentially beneficial culture-specific routines is ultimately dependent on the ability of senior management and corporate HR to develop comprehensive and stable informal relationships between expatriates and inpatriates. These informal relationships should evolve in such a manner that they smoothly produce procedural outcomes beneficial for the firm's performance. To achieve this goal, corporate entities must first insure complementary knowledge bases between expatriates and inpatriates prior to emphasizing the cultural fit. The emphasis on functional fit creates a "strong" situation for expatriates and inpatriates attenuating the influence of their cultural differences and stimulating the functional conflict between their diverse cognitive frames. The functional fit is important because emphasizing only cultural fit could be costly, slow, and achieved only at the loss of functional focus. Once this core competency of bundling expatriate and inpatriate managerial resources is mastered, the value-adding synergies within an SGHRM system can be derived.

\section{CONCLUSIONS}

The traditional bureaucratic model of management staffing in MNCs includes the principles of unidirectional dependence on hierarchical authority of the home country organization and on the reliance on formal corporate rules and 
standard expatriate-based staffing policies of the firm-level SGHRM. Its salient features are based on viewing foreign assignments of expatriates as job-related extensions of parent organization's hierarchical relationships accompanied by behavior-based individual rewards and accountability. However, the disruptive technological and organizational changes occurring within the globalization process make it very difficult to define a stable set of assignment tasks for expatriates to perform and to be measured against.

These changes encourage the introduction of an innovative SGHRM practice of inpatriation and development of a competency-based approach to global management staffing system. The innovative SGHRM system fosters a "flexibility" beyond the internal cultural "fit" - a flexibility coherent with the "fit" among the strategic choices of global business strategies, patterns of individual competencies and capabilities, and the characteristics of the local environments. Within this framework, the ultimate goal of an SGHRM system should be to exploit synergies in individual managerial competencies thus increasing the effectiveness of coordination of efforts among global subsidiaries while not sacrificing local responsiveness. Focusing on the candidates' social knowledge, cognitively flexible skills, and technical competence rather than on the nature of their jobs, the corporate SGHRM system must insure that individual expatriates and inpatriates have the ability to learn and develop a flexible set of skills and competencies rather than making the trade-off approach based on the candidates' past skills and capabilities acquired in the home and host country organizations.

The significance of the inpatriation process in the strategic global HRM policies and practices is positively related to the global organizations' emphasis on the development of organizational capabilities: quality, speed, low-cost operations, learning, innovation, and customer focus (Lawler, 1996; Urlich \& Lake, 1990). This emerging SGHRM strategic intent-enhancing view of individual competencies is associated with the corporate focus on high individual performance of globally assigned managers. The selection process in such SGHRM systems is designed for hiring the candidates who possess more than needed competencies and involves the global compensation system designed to reward the selected candidates who display these competencies (Milkovich \& Bloom, 1998). The competency-based SGHRM system fostering learning through interactive socialization and teamwork of expatriates and inpatriates is different from the historical assignment-based system fostering top-down headquarters control and up front selection of candidates securing organizational stability. In other words, the inpatriation process is activated through emphasis on flexibility whereas the expatriation process is activated through push for fit in SGHRM practices of staffing candidates in the network of the global organization.

SGHRM systems can thus become firm strategic resources that expand the range of corporate strategic choices leading to a sustained competitive advantage. The key reason for development of this firm-specific resource approach to global staffing is the resulting dynamic capabilities model, which allows the appropriate incorporation of inpatriate candidates into the corporate leader- 
ship strategies for global integration. This resource variation produced by strategic inclusion and development of inpatriate managerial resources leads to a broadened repertoire of strategic choices, which may contribute to the advantageous development of the firm's global capabilities. With this purpose in mind, the particular contribution of this article lies in providing a theorybased model for an innovative corporate SGHRM system designed as a resource-based approach to identify and develop competent global leaders.

Future research should address the contextual influences on SGHRM systems - particularly the influence of the firm's resource configuration, corporate culture, organizational learning, and intellectual capital composition, as well as the influence of internal controls and integrative mechanisms employed in global diversification strategies. A more specific line of research should address the design of inpatriation policy in global organizations as a function of structure, incentives, communication processes, and member composition. The issues of global strategic leadership are critical particularly in strategic alliances, networks, and ultimately in TMT succession plans. In our opinion, the proper integration of a global mind-set construct in global leadership development of expatriates and inpatriates will be the most intriguing future research topic related to the SGHRM systems development.

\section{REFERENCES}

Aaker, D., \& Jacobsen, D. (1994). The financial information content of preserved quality. Journal of Marketing Research, 31, (May), 191-201.

Adler, N., \& Ghadar, F. (1989). Globalization and human resource management. In A. Rugman (Ed.), Research in global strategic management: A Canadian perspective (Vol. 1, pp. 179-205). Greenwich, CN: JAI Press.

Aguirre, M. (1997). Multiculturalism in a labour market with integrated economies. Management Decision, 35(7), 489-496.

Amit, R., \& Schoemaker, P. (1993). Strategic assets and organizational rent. Strategic Management Journal, 14, 33-46.

Anderson, J., \& Narus, J. (1990). A model of distributor firm and manufacturing firm working partnership. Journal of Marketing, 54, (January), 42-58.

Anderson, O. (1993). On the internationalization process of firms: A critical analysis. Journal of International Business Studies, 24(2), 209-231.

Arnold, D., \& Quelch, J. (1998). New strategies in emerging markets. Sloan Management Review, 40(1), 7-20.

Athanassiou, N., \& Nigh, D. (1992). The impact of U.S. company internationalization on top management advice network: A tacit knowledge perspective. Strategic Management Journal, 20(1), 83-92.

Barney, C. (1991). Firm resources and sustained competitive advantage. Journal of Management, 17, 99-120.

Barney, J., \& Wright, P. (1998). On becoming a strategic partner: The role of human resources in gaining competitive advantage. Human Resources Management, 37(1), 31-46.

Bartlett, C. (1986). Building and managing the transnational: The new organizational challenge. In M. Porter (Ed.), Competition in global industries (pp. 367-404). Boston, MA: Harvard Business School Press. 
Bartlett, C., \& Ghoshal, S. (1994). Changing the role of top management: Beyond strategy to purpose. Harvard Business Review, 72(6), 79-88.

Bartlett, C., \& Goshal, S. (1995). Changing role of top management: Beyond structure to purpose. Harvard Business Review, 73(4), 86-96.

Bartmess, A., \& Cerny, K. (1983). Building competitive advantage through a global network of capabilities. California Management Review, 35(2), 79-103.

Birkinshaw, J., Hood, N., \& Jonsson, S. (1998). Building firm-specific advantages in multinational corporations: The role of subsidiary initiative. Strategic Management Journal, 19, 221-224.

Bridging the gaps: The World Health report. (1995). Geneva: World Health Organization. pp. $37-38$.

Burt, R. (1992). Structural holes. Cambridge: Harvard University Press.

Cappeli, P., \& Singh, H. (1992). Integrating strategic human resources with strategic management. In D. Lewin, O. S. Mitchell, \& D. Sherer (Eds.), Research frontiers in IR and HR (pp. 165-192). Madison, WI: IRRA.

Child, J. (1996). Strategic choice in the analysis of action structure, organizations and environment: Retrospect and prospect. Organization Studies, 18(1), 43-76.

Collis, D. (1991). A resource-based analysis of global competition: The case of the bearings industry. Strategic Management Journal, 12, 49-68.

Conner, K. (1991). A historical comparison of resource-based theory and five schools of thought within industrial organizational economies: Do we have a new theory of the firm? Journal of Management, 17, 121-154.

Constantin, J., \& Lusch, R. (1994). Understanding resource management. Oxford, OH: The Planning Forum.

Dadfer, H., \& Gustavsson, P. (1992). Competition by effective management of cultural diversity. International Studies of Management and Organization, 22(4), 81-92.

Day, G. (1994). The capabilities of market-driven organizations. Journal of Marketing, 58, (October), 37-52.

Day, G., \& Fahey, L. (1988). Valuing marketing strategies. Journal of Marketing, 52, (July), 45-57.

Dierickx, I., \& Cool, K. (1989). Asset stock accumulation and sustainability of competitive advantage. Management Science, 35(12), 1504-1511.

Douglas, S., \& Craig, S. (1991). Spatial dimensions of international markets. In A. Ghosh, \& C. Ingene (Eds.), Spatial analysis in marketing: Theory, methods, and applications. Greenwich: JAI Press.

Doz, Y., \& Prahalad, C. (1987). Multinational companies' missions: Balancing national responsiveness and global integration. New York: Free Press.

Drucker, P. (1993). Post-capitalist society. New York: Harper Business.

Dyer, J., \& Singh, H. (1998). The relational view: Cooperative strategy and sources of interorganizational competitive advantage. Academy of Management Review, 23(4), $660-679$.

Dykeman, J. (1995). HR takes an active role in selecting global IT staff. Managing Office Technology, (March), 43-45.

Fladmoe-Laindquist, K., \& Tallman, S. (1994). Resource-based strategy and competitive advantage among multinationals. In P. Shrivastava, A. Huff, \& J. Dutton (Eds.), Advances in strategic management. Greenwich, CT: JAI Press.

Flamholtz, E., \& Lacey, J. (1981). Personnel management: Human capital theory and human resource accounting. Los Angeles, CA: Institute of Industrial Relations, USLA.

Frey-Ridgway, S. (1997). The cultural dimensions of international business. Collection Building, 16(1), 12-23. 
Fuschberg, G. (1992). As costs of overseas assignments climb, firms select expatriates more carefully. Wall Street Journal, (January 9), 81.

Garten, J. (1996). The big emerging markets. Columbia Journal of World Business, 31(3), 6-31.

Garten, J. (1997a). Troubles ahead in emerging markets. Harvard Business Review, 75(3), $38-50$.

Garten, J. (1997b). The Big Ten: The emerging markets and how they will changes our lives. New York: Basic Books.

Ghoshal, S. (1987). Global stategy: An organizing framework. Strategic Management Journal, 8(3), 425-440.

Ghoshal, S., \& Bartlett, C. (1997). The individual corporation: A fundamentally new approach to management. New York: Harper Business.

Granstrand, O., Hakanson, L., \& Sjölander, S. (1993). Internationalization of R\&D-A survey of some recent research. Research Policy, 22, 413-430.

Gregersen, H., Morrison, A., \& Black, S. (1998). Developing leaders for the global frontier. Sloan Management Review, 40(1), 21-32.

Hall, R. (1993). A framework linking intangible resources and capabilities to sustainable competitive advantage. Strategic Management Journal, 14, 607-618.

Harvey, M. (1993). Training inpatriate managers to succeed in the domestic organization. Proceedings of the Fourth Symposium on Cross-cultural Consumer and Business Studies, (pp. 210-216).

Harvey, M. (1997). Inpatriation training: The next challenge for international human resource management. International Journal of Intercultural Relations, 21(3), 393-428.

Harvey, M., \& Buckley, M. (1997). Managing inpatriates: Building global core competency. Journal of World Business, 32(1), 35-52.

Harvey, M., \& Lusch, R. (1997). Protecting the core competencies of a company: Intangible asset security. European Management Journal, 15(4), 370-380.

Harvey, M., \& Miceli, N. (1999). Exploring inpatriate manager issues: An empirical study. International Journal of Intercultural Relations (in press).

Harvey, M., Speier, C., \& Novicevic, M. (1999a). The role of inpatriates in a globalization strategy and challenges associated with the inpatriation process. Human Resource Planning, 22(1), 38-50.

Harvey, M., Spier, C., \& Novicevic, M. (1999b). The role of inpatriation in global staffing. International Journal of Human Resource Management (in press), 10(3).

Harvey, M., Spier, C., \& Novicevic, M. (1999c). Inpatriate managers: How to increase the probability of success. Human Resource Management Review (in press).

Harvey, M., Spier, C., \& Novicevic, M. (1999d). An innovative global management staffing system: A competency-based perspective. Human Resource Management Journal (in press).

Hofstede, G. (1980). Culture's consequences: International differences in work-related values. Beverly Hills, CA: Sage Publications.

Hofstede, G. (1984). Culture's consequences: International differences in work-related values. Beverly Hills, CA: Sage Publications (Abridged edn.).

Hunt, S., \& Morgan, R. (1995). The competitive advantage theory of competition. Journal of Marketing, 58, (April), 1-15.

Kamoche, K. (1996). Strategic human resource management within a resource-capability view of the firm. Journal of Management Studies, 20(2), (March), 213-233.

Kerin, R., Varadarjan, R., \& Peterson, R. (1992). First-mover advantage: A synthesis, conceptual framework and research propositions. Journal of Marketing, 56, (October), $33-52$. 
Klein, J., Edge, G., \& Kass, T. (1991). Skill-based competition. Journal of General Management, 16, 1-15.

Kobrin, S. (1988). Expatriate reduction and strategic control in American multinational corporations. Human Resource Management Journal, 27(1), 63-75.

Kogut, B. (1985). Designing global strategy: Profiting from operational flexibility. Sloan Management Review, 27(1), 27-38.

Kogut, B., \& Zander, I. (1992). Knowledge of a firm, combinative capabilities, and the replication of technology. Organization Science, 3(3), 383-397.

Lado, A., \& Wilson, M. (1994). Human resource systems and sustained competitive advantage: A competency-based perspective. Academy of Management Review, 19, 699-727.

Lawler, E. III. (1996). From ground up: Six principles of building the new logic corporation. San Francisco: Jossey-Bass.

Leonard-Barton, D. (1995). Wellsprings of knowledge: Building and sustaining the sources of innovation. Boston: Harvard Business School Press.

McBride, M. (1992). Management development in the global village. Journal of Management Development, 11, 48-58.

McMillen, M., Baker, A., \& White, J. (1997). Cultural analysis, "good conversation" and the creation of multicultural learning organizations. Management Learning, 28(2), 197-216.

Milkovich, J., \& Bloom, M. (1998). Rethinking international compensation. Compensation and Benefits Review, (April), 15-23.

Morgan, R., \& Hunt, S. (1994). The commitment-trust theory of relationships marketing. Journal of Marketing, 58, (July), 36-51.

Nahapiet, J., \& Ghoshal, S. (1998). Social capital, intellectual capital, and the organizational advantage. Academy of Management Review, 23(3), 242-266.

Nemetz, P., \& Christensen, S. (1996). The challenge of cultural diversity: Harnessing a diversity of views to understand multiculturalism. Academy of Management Review, 21(2), 434-463.

Nevin, J. (1995). Relationship marketing and distribution channels: Exploring fundamental issues. Journal of Academy of Marketing Science, 23, (Fall), 327-334.

Oliver, C. (1997). Sustainable competitive advantage: Combining institutional and resource-based views. Strategic Management Journal, 18(9), 697-713.

Pechter, K. (1993). The foreigners are coming. International Business, September, 55-60.

Penrose, E. (1959). The theory of growth of the firm. Oxford: Blackwell.

Perlmutter, H. (1969). The tortuous evolution of multinational corporations. The Columbia Journal of World Business, 4(1), (January-February), 9-18.

Pfeffer, J. (1994). Competitive advantages through people. Boston: Harvard Business School Press.

Pine, J. (1993). Mass customization: The new frontier in business competition. Boston: Harvard Business School Press.

Reynolds, C. (1997). Strategic employment of third country nationals: Keys to sustaining the transformation of HR functions. Human Resource Planning, 20(1), 33-40.

Roth, K. (1995). Managing international interdependence: CEO characteristics in a resource-based framework. Academy of Management Journal, 38(1), 200-231.

Roth, K., \& Nigh, D. (1992). The effectiveness of headquarters-subsidiary relations. Journal of Business Research, 23(1), 1-25

Roth, K., \& O'Donnell, S. (1996). Foreign subsidiary compensation strategy: An agency theory perspective. Academy of Management Journal, 39(3), 678-703.

Sanders, W., \& Carpenter, M. (1998). Internationalization and firm governance: The roles of CEO compensation, top team composition, and board structure. Academy of Management Journal, 41(2), 158-178. 
Schien, E. (1983). The role of the founder in creating organizational culture. Organizational Dynamics, 12, 13-28.

Schuler, R., Dowling, P., \& De Cieri, H. (1993). An integrative framework of strategic international human resource management. International Journal of Human Resource Management, 1, 717-764.

Schumpter, J. (1934). The theory of economic development. Cambridge MA: Harvard University Press.

Schumpter, J. (1942). Capitalism, socialism, and democracy. New York: Harper.

Snow, C., \& Herbiniak, L. (1980). Strategic, distinctive competence, and organizational performance. Administrative Science Quarterly, 25, 165-191.

Sparrow, P. (1994). Organizational competencies: Creating a strategic framework for selection and assessment. In N. Anderson, \& P. Herriot (Eds.), Handbook of assessment and appraisal. London: Wiley.

Strivastava, R., Shervani, T., \& Fahey, L. (1998). Market-based assets and shareholder value: A framework for analysis. Journal of Marketing, 62(1), 774.

Sullivan, D. (1994). Measuring the degree of internationalization of a firm. Journal of International Business Studies, 25(2), 325-342.

Taylor, S., Beechler, S., \& Napier, N. (1996). Toward an integrative model of strategic international human resource management. Academy of Management Review, 21(4), 959-985.

Teece, D. (1982). Towards an economic theory of the multiproduct firm. Journal of Economic Behavior and Organization, 3, 39-63.

Teece, D. (1988). Technological change and the nature of the firm. In G. Dosi, C. Freeman, R. Nelson, G. Silverberg, \& I. Soete (Eds.), Technology change and economic theory (pp. 256-281). New York: Pinter Publications.

Teece, D., Pisano, G., \& Shuen, A. (1997). Dynamic capabilities and strategic management. Strategic Management Journal, 18(7), 509-533.

The discrete chain of the multicultural multinational. (1994). Economist, (July 30), 57-58.

The state of world population. (1995). New York: United Nations Population Fund.

Ulrich, D. (1993). Profiling organizational competitiveness: Cultivating capabilities. Human Resource Planning, 16(3), 1-17.

Ulrich, D., \& Lake, D. (1990). Organizational capability. New York: Wiley.

World population prospects: The 1994 revision. (1995). New York: United Nations Population Division. pp. $232-233$. 